\title{
PENGEMBANGAN SAYURAN INDIJENES BERKHASIAT OBAT DILAHAN PERKARANGAN UNTUK MENINGKATKAN KESEHATAN DAN PENDAPATAN KELUARGA
}

\section{THE DEVELOPMENT AF INDIGENOUS VEGETABLES THAT HAVE MEDICINAL PROPERTI IN THE YARD TO IMPROVE HEALTH AND FAMILY INCOME}

\author{
W Nahraeni1a, A Rahayu1, V Rochman'1 \\ ${ }^{1}$ Program Studi Agribisnis, Fakultas Pertanian,Universitas Djuanda Jl. Tol. No.1, Ciawi Pos 35 Bogor 16720. \\ a'Korespondensi:Wini Nahraeni; E-mail: winisivadevi@unida.ac.id \\ (Diterima: 25-09-2019; Ditelaah: 26-09-2019; Disetujui: 10-10-2019)
}

\begin{abstract}
One of the yard's functions is for in situ conservation of various genetic resources of germplasm, including local vegetables (indigenous), which are not only consumed because of their nutritional content, but also their medicinal properties. This community service activity aims to encourage the optimization of the use of the yard through the cultivation of medicinal vegetables which has medicinal properties in Cisaat District in Sukabumi Regency. The activity was carried out by lecturers and students of the Agribusiness and Agrotechnology Study Program, Faculty of Agriculture, University of Djuanda by involving housewives of PKK cadres, Posyandu cadres and non-cadres in Babakan Village, Cisaat District, Sukabumi Regency. The stages of activities carried out included: a. developing the adult approach method; b. observations on the conditions of knowledge and application of cultivation, postharvest processing and analysis of medicinal vegetable plants in medicinal properties in the yard, c. conducting counseling and training using lecture methods and demonstration methods and demonstration plots, d. monitoring and evaluation, in the form of visits to partner group yards, e. program sustainability. The results of counseling and training showed an increase in the understanding of the participants about the function and importance of the use of the plot of land, knowledge of medicinal indijenes, medicinal knowledge and skills about indijenes medicinal cultivation of medicine, yield processing, analysis of simple farming and product marketing.
\end{abstract}

Keywords : Analysis of simple farming, demonstration plot, yard.

\begin{abstract}
ABSTRAK
Salah satu fungsi pekarangan adalah untuk konservasi in situ berbagai sumberdaya genetik plasma nutfah, termasuk sayuran lokal (indijines), yang tidak hanya dikonsumsi karena kandungan gizinya, tetapi juga kandungan zat berkhasiat obat. Kegiatan pengabdian kepada masyarakat ini bertujuan untuk mendorong optimalisasi pemanfaatan lahan pekarangan melalui budidaya tanaman sayuran indijenes berkhasiat obat di Kecamatan Cisaat di Kabupaten Sukabumi. Kegiatan dilaksanakan oleh dosen dan mahasiswa Program Studi Agribisnis dan Agroteknologi Fakultas Pertanian Universitas Djuanda dengan melibatkan ibu rumah tangga kader PKK, kader Posyandu dan non kader di Desa Babakan Kecamatan Cisaat Kabupaten Sukabumi.Tahapan kegiatan yang dilakukan meliputi: a. menyusun metode pendekatan orang dewasa (POD); b. observasi mengenai kondisi pengetahuan dan penerapan budidaya, pengolahan pascapanen dan analisis usahatani
\end{abstract}


tanaman sayuran indijenes berkhasiat obat di lahan pekarangan, c. pelaksanaan penyuluhan dan pelatihan dengan metode ceramah dan demonstrasi cara dan demonstrasi plot (demplot), d. monitoring dan evaluasi, berupa kunjungan ke lahan pekarangan kelompok mitra, e. keberlanjutan program. Hasil penyuluhan dan pelatihan menunjukkan adanya peningkatan pemahaman para peserta tentang fungsi dan arti penting pemanfaatan lahan pekarangan, pengetahuan tentang sayuran indijenes berkhasiat obat, pengetahuan dan keterampilan tentang budidaya sayuran indijenes berkhasiat obat, pengolahan hasil, analisis usahatani sederhana dan pemasaran produk.

Kata kunci: Analisis usahatani, demplot, pekarangan.

Nahraeni, W., Rahayu, A., \& Nurrokhmanuddin. W. (2019). Pengembangan Sayuran Indijenes

Berkhasiat Obat di Lahan Perkarangan Untuk Meningkatkan Kesehatan dan Pendapatan Keluarga.

Jurnal Qardhul Hasan; Media Pengabdian kepada Masyarakat, 5(2), 101-106.

\section{PENDAHULUAN}

Ditinjau dari aspek lingkungan, pekarangan rumah merupakan lingkungan mikro konservasi in situ berbagai sumberdaya genetik sayuran indijines. Sayuran indijenes terdiri atas sayuran asli daerah atau introduksi yang telah lama dibudidayakan, dikonsumsi dan berkembang di masyarakat di suatu daerah. Peluang pengembangan sayuran indijenes di lahan sempit memiliki prospek yang baik, mengingat tanaman indijenes mudah ditanam, toleran terhadap berbagai kondisi tanah dan iklim, resisten terhadap hama dan penyakit dan dapat menambah pendapatan keluarga. Selain itu tanaman indijenes mampu tumbuh dengan input eksternal yang rendah (Hughes et al., 2013). Upaya pengembangan sayuran indijines juga dilakukan sebagai alternatif sumber mikronutrien (zat berkhasiat) murah dan sekaligus memperkuat basis ketahanan pangan (Adiyoga, 2008).

Kandungan gizi sayuran indijenes beragam, dari 9 jenis yang diamati, kandungan protein, lemak dan fosfor tertinggi terdapat pada buah muda kecipir, kalsium, vitamin A dan vitamin C tertinggi pada katuk. Kandungan flavonoid, fenolik total dan aktivitas antioksidan tanaman sayuran daun Indonesia relatif tinggi. Dari 11 sayuran yang diamati, kandungan fenolik total berkisar $0.334-1.52 \mathrm{mg} / \mathrm{g}$, aktivitas antioksidan yang diukur dengan DPPH sebesar 5.93-112 $\mu \mathrm{mol} / \mathrm{g}$, dan flavonoid total $0.30-143 \mathrm{mg} / 100 \mathrm{~g}$. Kandungan fenolik total dan aktivitas antioksidan tertinggi terdapat pada kenikir, sedangkan flavonoid total terbesar pada katuk (Andarwulan et al., 2010). Selain dikonsumsi sebagai lalapan atau masakan sehari-hari, sayuran indijenes juga dimanfaatkan sebagai obat. Hasil eksplorasi di sekitar Cagar Alam Gunung Simpang Jawa Barat, diperoleh 74 jenis tumbuhan yang dimanfaatkan sebagai obat (Handayani, 2015), sebagian besar tumbuhan tersebut tergolong sayuran indijenes. Dengan demikian upaya pemanfaatan pekarangan dengan tanaman yang bermanfaat sebagai sayuran dan obat perlu dilakukan, untuk meningkatkan konsumsi gizi, kesehatan dan pendapatan keluarga.

Upaya intensifikasi pekarangan telah dilakukan dan didukung oleh program pemerintah. Pada tahun 2009, Kementrian Pertanian telah menerbitkan Peraturan Presiden No 22 Tahun 2009 tentang Kebijakan Percepatan Penganekaragaman Konsumsi Pangan Berbasis Sumberdaya Lokal (P2KP). Selanjutnya Dirjen Hortikultura melaksanakan Gerakan Perempuan untuk Optimalisasi Pekarangan (GPOP) dengan komoditas utama sayuran, tanaman obat, dan tanaman hias. Kementrian Pertanian menginisiasi optimalisasi pemanfaatan lahan pekarangan melalui Konsep Rumah Pangan Lestari (KRPL) pada tahun 2012.

Salah satu daerah yang potensial untuk pengembangan sayuran indijenes berkhasiat obat adalah Kecamatan Cisaat di 
Kabupaten Sukabumi. Desa Babakan mempunyai luas lahan sebesar $220 \mathrm{Ha}$, dengan $40 \%$ merupakaan lahan pertanian. Penduduk Desa Babakan berjumlah 6741 jiwa, yang terdiri atas 51\% laki-laki dan 49\% perempuan (Kecamatan Cisaat dalam Angka 2018 Badan Pusat Statistik Kabupaten Sukabumi). Sebagian besar penduduk perempuan berprofesi sebagai ibu rumah tangga dan tidak mempunyai pekerjaan tetap, namun mereka mempunyai potensi besar untuk berkembang terlihat dari aktivitas mereka dalam kegiatan PKK dan Posyandu.

Luas lahan pekarangan di Desa Babakan rata-rata sebesar $24 \mathrm{~m} 2$ (Monograf Desa Babakan, 2017). Lahan pekarangan di dalam kompleks perumahan yang terdapat di Desa Babakan rata-rata seluas $15 \mathrm{~m}^{2}$. Sementara itu di luar kompleks perumahan, luas pekarangan beragam berkisar antara 15$100 \mathrm{~m}^{2}$.

Selama ini fakta menunjukkan pengelolaan pekarangan belum dimanfatkan secara optimal. Hal ini disebabkan oleh pengetahuan mengenai manfaat lahan pekarangan dan teknik budidayanya yang masih terbatas, demikian pula dengan sarana produksi dan penyuluhan serta bantuan luar untuk kegiatan optimalisasi lahan pekarangan.

Dengan keterbatasan luas lahan pekarangan, maka pemanfaatan dan pengelolaan lingkungan dapat dioptimalkan dengan penanaman sayuran indijenes yang berpotensi sebagai tanaman obat keluarga (TOGA). Berdasarkan observasi di lapangan sebelumnya diketahui bahwa beberapa ibu rumah tangga telah menanam sayuran indijenes berkhasiat obat, namun dalam jenis dan jumlah yang terbatas. Hasil temuan sebelumnya juga menyatakan bahwa sebagian dari mereka telah mengetahui khasiat dan manfaat sayuran indijenes, namun mereka belum memahami khasiat sayuran indijenes secara ilmiah. Oleh karena itu perlu dilakukan pelatihan tentang budidaya, manfaat, khasiat sayuran indijenes berkhasiat obat agar masyarakat yang telah memiliki pengetahuan tersebut dapat membudidayakan dan memanfaatkannya, sehingga akan terwujud prinsip kemandirian dalam pengobatan keluarga. Selain itu juga dapat dikembangkan menjadi usaha kecil dan menengah di bidang obat-obatan herbal, yang selanjutnya dapat disalurkan ke masyarakat.

Desa Babakan memiliki satu organisasi PKK desa dengan jumlah anggota kurang lebih 40 orang kader, dan 10 organisasi PKK RW. Desa ini juga mempunyai 10 Posyandu dengan jumlah 50 orang kader yang membina $10 \mathrm{RW}$ dan 35 RT. Di antara 10 RW tersebut, terdapat satu RW (RW 10) yang berada dalam kompleks perumahan, sedangkan sembilan RW lain di pemukiman biasa. Kader terpilih adalah ibu rumah tangga yang potensial untuk menularkan ilmu dan teknologi yang diperoleh kepada ibu rumah tangga lain, sehingga kegiatan ini dapat berjalan secara berkelanjutan (sustainable).

Berdasarkan hasil pengamatan survey pendahuluan dan wawancara dengan Ketua Tim PKK dan beberapa kader PKK di Desa Babakan Kecamatan Cisaat Kabupaten Sukabumi, diperoleh beberapa permasalahan yaitu: Pengetahuan kelompok mitra mengenai keanekaragaman dan keragaman sayuran indijenes berkhasiat obat masih terbatas; Pengetahuan kelompok mitra mengenai pemanfaatan dan khasiat sayuran indijenes masih terbatas; Penguasaan teknik budidaya tanaman di pekarangan yang efisien (hemat lahan, pupuk, air, pestisida) dan ramah lingkungan masih terbatas, sehingga perlu diperkenalkan teknik hidroponik dan vertical garden; Terbatasnya paket teknologi (termasuk bibit, sarana produksi, wadah tanam/pot. media tanam, pupuk, pestisida nabati) untuk tanaman indijenes berpotensi TOGA sehingga perlu diberikan bantuan yang diperlukan pada tahap awal kegiatan sabagai sarana untuk menambah koleksi tanaman TOGA; Sebagian besar kelompok mitra belum memahami cara menganalisis usaha di lahan pekarangan, termasuk pencatatan usaha dan 
pembukuannya; Kelompok mitra masih belum mengetahui teknik pasca panen tumbuhan obat, berupa pemanenan, pencucian, pengeringan dan penyimpanan yang benar; Kelompok mitra masih mengelola pekarangan secara subsisten untuk keperluan keluarga, tanpa memperhitungkan kemungkinan menjadi usaha yang menguntungkan; Pengetahuan kelompok mitra mengenai pengolahan sayuran indijenes dan TOGA masih terbatas.

\section{MATERI DAN METODE}

Kelompok mitra sasaran kegiatan pengabdian ini adalah ibu rumah tangga di Desa Babakan yang terdiri atas 20 orang pengurus PKK perwakilan dari $10 \mathrm{RW}$ dan 10 orang kader Posyandu. Para peserta dalam program ini diharapkan dapat menularkan pengetahuan tentang sayuran indijenes berkhasiat obat yang diperolehnya kepada para ibu rumah tangga di lingkungannya.

Tahapan dan langkah-langkah yang akan dilakukan untuk melaksanakan solusi yang ditawarkan adalah:

\section{Menyusun Metode Pendekatan}

Dalam kegiatan pengabdian ini metode yang digunakan adalah metode pendekatan orang dewasa (POD). Metode ini memiliki karakteristik berupa pembelajaran menuju ke arah pendewasaan atau ke arah kemampuan mengarahkan diri sendiri, pembelajaran lebih utama menggunakan eksperimen, diskusi, pemecahan masalah, latihan, simulasi dan praktek lapangan. Selain itu dalam metode ini program belajar disusun sesuai dengan kebutuhan dan kesiapan peserta didik. Metode yang digunakan berupa penyuluhan dengan cara ceramah, diskusi kelompok, dan praktik keterampilan, yang dilakukan secara partisipatif. Praktik lapangan meliputi demonstrasi cara, demonstrasi plot (demplot), pendampingan dan terakhir kunjungan lapang.

\section{Persiapan dan Observasi}

Sebelum kegiatan pengabdian ini dilaksanakan, terlebih dahulu dilakukan: pretest tentang pemahaman kelompok mitra mengenai sayuran indijenes dan tanaman obat buat keluarga (TOGA); pengamatan jenis tanaman yang ditanam di lahan pekarangan kelompok mitra; pengamatan teknik budidaya yang telah diterapkan oleh kelompok mitra di lahan pekarangan; pengetahuan tentang teknik budidaya dalam wadah, teknik hidroponik dan vertical garden; pengetahuan kelompok mitra mengenai cara pengolahan sayuran indijenes yang enak dimakan dan berkhasiat obat serta cara panen, pengeringan, penyimpanan; pemahaman mitra tentang analisis usaha tanaman sayuran indijenes di pekarangan Berdasarkan hasil pre-test dan pengamatan di lapangan, maka disusun materi penyuluhan, pelatihan dan praktik keterampilan yang tepat.

\section{Tahap Pelaksanaan}

Pada tahap pelaksanaan akan dilakukan penyuluhan dengan metode ceramah dan demonstrasi plot (demplot). Tujuan penyuluhan adalah untuk meningkatkan pengetahuan kelompok mitra, sedangkan demonstrasi cara dan demplot bertujuan untuk meningkatkan ketrampilan dalam kegiatan teknik budidaya dan pengolahan sayuran indijenes. Demonstrasi merupakan metode penyuluhan yang dilakukan dengan cara peragaan. Kegiatan demonstrasi dilakukan dengan maksud agar memperlihatkan suatu inovasi baru kepada sasaran secara nyata atau konkret. Melalui kegiatan demonstrasi sasaran (audience) diajarkan mengenai keterampilan, memperagakan cara kerja teknik-teknik baru termasuk keunggulannya untuk menyempurnakan cara lama (Balai Besar Pelatihan Pertanian Lembang, 2015). Dalam penyuluhan pertanian dikenal ada dua macam demonstrasi, yaitu 1) demonstrasi cara, dan 2) demonstrasi hasil

Untuk mendukung program ini dilakukan bantuan sarana berupa benih/bibit tanaman obat, sayuran, wadah tanam/pot, media 
tanam, pupuk, pestisida nabati, paralon, media tanam untuk hidroponik. Selain itu dilakukan pula kegiatan pendampingan, monitoring dan evaluasi. Kegiatan monitoring berupa kunjungan ke lahan pekarangan kelompok mitra. Evaluasi dilakukan terhadap kemampuan mitra memahami peran sayuran indijenes berkhasiat obat, teknik budidaya, cara panen, pengeringan, dan penyimpanan, pengolahan hasil dan manajemen usahataninya, menggunakan kuesioner (post test).

\section{HASIL DAN PEMBAHASAN}

\section{Kegiatan Survey dan Kegiatan Persiapan Pelaksanaan}

Pada bulan April 2019 telah dilakukan survey ke Desa Babakan, dengan cara mendatangi kepala desa dan ketua penggerak tim PKK desa (Ibu Rohayati). Kegiatan survey dilanjutkan ke kader posyandu dan kader PKK desa dengan tujuan mendiskusikan calon peserta kader dan nonkader PKK dan posyandu yang akan diikutkan dalam kegiatan pelatihan. Selain itu dibicarakan pula mengenai waktu, tempat kegiatan persiapan dan pelaksanaan pelatihan budidaya sayuran indijenes berkhasiat obat.

Berdasarkan hasil wawancara pada pertemuan awal dengan kader PKK diperoleh informasi bahwa masalah utama dalam pengelolaan lahan pekarangan adalah belum tahu arti penting lahan pekarangan terutama secara ekonomi, arti dan fungsi sayuran indijenes berkhasiat obat, teknik budidaya secara vertikultur dan hidroponik, belum adanya bantuan teknologi untuk memanfaatkan lahan pekarangan, terbatasnya pengetahuan tentang pengolahan sayuran indijenes berkhasiat obat. Dengan demikian kegiatan pengabdian ini dirancang dengan membuat programprogram: penyuluhan tentang arti penting pekarangan secara sosial, ekonomi, dan ekologi, pengertian dan peranan, serta fungsi sayuran indijenes berkhasiat obat, teknik budidaya sayuran indijenes, teknik budidaya tanaman obat yang efisien (di dalam pot/wadah, vertical garden), pembuatan hidroponik, dan manajemen usaha lahan pekarangan Selain itu dilakukan juga bantuan teknologi seperti benih/bibit tanaman obat, sayuran indijenes, wadah tanam/pot. media tanam (arang sekam dan pupuk organik) alat pertanian sederhana, pupuk, perlengkapan instalasi hidroponik (rockwool, benih pakcoy dan selada keriting, nutrisi, instalasi hidroponik).

\section{Tahap Pelaksanaan}

Kegiatan Pengabdian kepada Masyarakat di Kelompok PKK Desa Babakan Kecamatan Cisaat dimulai pada bulan April 2019. Hingga bulan bulan Agustus 2019 kegiatan yang telah dilakukan adalah : Ceramah dan diskusi tentang manfaat lahan pekarangan dan teknik budidaya tanaman sayuran indijenes berkhasiat obat yang efisien (di dalam pot/wadah, vertical garden), persiapan benih bermutu baik dan praktek pembuatan pesemaian; Praktek membuat media tanam dan pesemaian, untuk komoditas paria, kemangi, oyong, kenikir, katuk, dan beluntas. Tanaman lainnya adalah cabe rawit merah, cabe merah keriting, pakcoy, dan selada; Ceramah, diskusi dan praktek analisis ekonomi (perhitungan) usahatani; Pemindahan tanaman dari wadah semai ke dalam polibag; Ceramah dan diskusi pengolahan lahan untuk pengisian polibag berukuran $30 \times 40 \mathrm{~cm}$, pemupukan dan pemeliharaan tanam, pengendalian hama dan penyakit, teknik dan waktu panen yang tepat; Pendistribusian tanaman sayuran indijenes berkhasiat obat ke lahan pekarangan masing-masing peserta.

Pembuatan minuman kesehatan, dengan komposisi jahe, kayu secang, biji cengkeh, cabe jawa, serai, gula pasir, dengan tambahan kenikir dan katuk (13 April 2019) Pemasaran produk minuman kesehatan ke staf dan pengunjung Pusat Kesehatan Masyarakat Kecamatan Cisaaat.

Pelatihan budidaya tanaman secara hidroponik (instruktur alumni Prodi Agroteknologi), dengan tahapan pembuatan 
pesemaian untuk tanaman pakcoy menggunakan rockwool, pemberian nutrisi, pemeliharaan, dan panen.

Pemberian bantuan sarana budidaya berupa benih, pupuk, polybag, arang sekam. pupuk organik, rockwool, nutrisi, instalasi hidroponik, netpot, dan lainnya. Pendampingan dan monitoring ke pekarangan peserta pelatihan, pemasaran 100 pot tanaman obat keluarga.

\section{KESIMPULAN}

Selama kegiatan pengabdian kepada masyarakat ini para peserta aktif mengikuti seluruh kegiatan mulai dari penyuluhan, pelatihan keterampilan, pembuatan demplot dan menerapkannya di lahan pekarangan rumahnya. Hasil pelatihan menunjukkan pemahaman para peserta tentang fungsi dan pentingnya pemanfaatan lahan pekarangan meningkat, pengetahuan tentang sayuran indijenes berkhasiat obat juga meningkat. Demikian halnya pengetahuan dan keterampilan tentang budidaya sayuran indijenes berkhasiat obat, pengolahan hasil, dan pemasaran telah dimiliki para peserta.

\section{UCAPAN TERIMAKASIH}

Terima kasih kepada Kementrian Riset, Teknologi dan Pendidikan Tinggi atas dana hibah yang diberikan melalui Program Pengabdian kepada Masyarakat (PKM) tahun 2019.

\section{DAFTAR PUSTAKA}

Adiyoga, W., M. Ameriana, dan T.A. Soetiarso. 2008. Segmentasi pasar dan Pemetaan Persepsi Atribut Produk Beberapa Jenis Sayuran Minor (UnderUtilized). Jurnal Hortikultura 18 (4):466-476.

Andarwulan, N., R. Batari, D.A. Sandrasari, B. Bolling, and H. Wijaya. 2010. Flavonoid content and antioxidant activity of vegetables from Indonesia. Food Chemistry 121:1231-1235.
Handayani A. 2015. Pemanfaatan tumbuhan berkhasiat obat oleh masyarakat sekitar Cagar Alam Gunung Simpang, Jawa Barat. PROS SEM NAS MASY BIODIV INDON 1 (6): 1425-1432.

Hughes, J.d'A.; Ebert, A.W. 2013. Research and Development of Underutilized Plant Species: The Role of Vegetables in Assuring Food and Nutritional Security. In Proceedings of the 2nd International Symposium on Underutilized Plant Species: Crops for the Future-Beyond Food Security; Massawe, F., Mayes, S., Alderson, P., Eds.; International Society for Horticultural Sciences (ISHS). Volume 2:79-91. Korbeek-Lo, Belgium.

Kecamatan Cisaat dalam Angka. 2018. Badab Pusat Statistik Kabupaten Sukabumi.

6. Kementrian Pertanian. 2012. Pengembangan Kawasan Rumah Lestari. Kementrian Pertanian dan SIKIB. Jakarta. 